\title{
Continuity in the photosynthetic production of dissolved organic carbon from eutrophic to oligotrophic waters
}

\author{
Emilio Marañón ${ }^{1,2, *}$, Pedro Cermeño ${ }^{1}$, Valesca Pérez ${ }^{1}$ \\ ${ }^{1}$ Departamento de Ecología y Biología Animal, Universidad de Vigo, 36200 Vigo, Spain \\ ${ }^{2}$ Laboratoire d'Océanographie de Villefranche, CNRS, Université de Paris 6, 06234 Villefranche-sur-Mer Cedex, France
}

\begin{abstract}
We studied the photosynthetic production of dissolved organic carbon (DOCp) during summer oligotrophic conditions in the Celtic Sea. The production rate of size-fractionated, particulate organic carbon ( $\mathrm{POCp}$ ) was also determined, as well as the relationship between irradiance and DOCp and the kinetics of DOCp during a $24 \mathrm{~h}$ light-dark cycle. Mean $( \pm 1 \mathrm{SE})$, euphotic layer-integrated POCp was $510 \pm 61 \mathrm{mg} \mathrm{C} \mathrm{m}^{-2} \mathrm{~d}^{-1}$, and cells in the $<5 \mu \mathrm{m}$ size fraction accounted for $58 \pm 3 \%$ and $63 \pm 4 \%$ of total integrated chlorophyll a concentration and POCp, respectively. The mean, integrated percentage of extracellular release [PER, calculated as DOCp / (DOCp + POCp)] was $22 \pm 2 \%$. $\mathrm{DO}^{14} \mathrm{C}$ accumulation stopped during the dark. In photosynthesis-irradiance experiments, DOCp remained constant across a wide irradiance range, despite the strong light dependence of POCp. These observations suggest that direct release from intact cells is the main pathway for DOCp. Significant DOCp took place throughout the euphotic layer and across a wide irradiance range, suggesting an important role for passive diffusion in the release of recent photosynthate. When comparing our measurements of DOCp in the Celtic Sea with previous observations in a coastal, eutrophic ecosystem, a remarkable continuity is observed, both in the relative significance and likely mechanisms of DOCp. Across a productivity range from $<100$ to $>15000 \mathrm{mg} \mathrm{C} \mathrm{m}^{-2} \mathrm{~d}^{-1}$, PER was relatively constant at $\sim 20 \%$, and integrated DOCp could be predicted from integrated POCp with the equation: $\log ($ DOCp $)=0.96 \times \log ($ POCp $)-0.51\left(\mathrm{r}^{2}=0.90, \mathrm{n}=35, \mathrm{p}<0.001\right)$.
\end{abstract}

KEY WORDS: Phytoplankton - Dissolved organic carbon · Oligotrophic conditions $\cdot$ Celtic Sea Resale or republication not permitted without written consent of the publisher

\section{INTRODUCTION}

Some of the carbon that has been recently photosynthesized by phytoplankton is released into the external medium as dissolved organic carbon (DOC). Sufficient evidence is available to demonstrate that the extracellular release of photosynthetic DOC is not a methodological artifact (Fogg 1983, Bjørnsen 1988), but a real phenomenon that may arise through direct release from intact cells (e.g. Obernosterer \& Herndl 1995, Malinsky-Rushansky \& Legrand 1996) and/or indirect mechanisms, such as cell lysis (Nagata 2000) or zooplankton grazing and egestion (Jumars et al. 1989). Knowledge of the magnitude, variability and mecha- nisms of photosynthetic DOC production (DOCp) is needed, not only to understand carbon cycling within the microbial food web, but also to refine global budgets of ocean productivity (del Giorgio \& Duarte 2002).

${ }^{14} \mathrm{C}$-based determinations of DOCp through the euphotic zone, per se, do not suffice to ascertain what mechanisms are responsible for the extracellular release of dissolved photosynthate. For instance, measuring the accumulation of $\mathrm{DO}^{14} \mathrm{C}$ during a conventional end-point ${ }^{14} \mathrm{C}$ experiment does not allow one to distinguish DOC production due to direct cell release from DOC production due to trophic mechanisms, such as zooplankton grazing and egestion. Similarly, determination of DOCp at different depths in the euphotic 
zone does not allow one to conclude unequivocally which environmental factors control the vertical variability in the relative importance of dissolved primary production. Additional approaches are therefore required, such as the experimental determination of the relationship between different environmental factors (e.g. temperature, irradiance, nutrient concentration) and DOCp (Zlotnik \& Dubinsky 1989, Obernosterer \& Herndl 1995), the monitoring of DOCp over light-dark cycles (Mague et al. 1980, Marañón et al. 2004), and the analysis of the biochemical composition of the released compounds (Obernosterer \& Herndl 1995, Meon \& Kirchman 2001).

Using some of these approaches, in conjunction with the determination of the vertical and seasonal variability of DOCp, we have recently addressed the significance and mechanisms of DOCp in a coastal, eutrophic ecosystem (Marañón et al. 2004). We observed that a high percentage $(>80 \%)$ of the variability in DOCp could be explained by the changes in the rate of particulate primary production (POCp). We also found that the relative contribution of DOCp to total, integrated primary production (PER) was relatively constant at around $20 \%$, irrespective of phytoplankton biomass, size-structure and productivity. Moreover, there was no DOC accumulation during the dark period, indicating that the release of recent photosynthate was a purely physiological, light-dependent process and that trophic mechanisms were not involved in DOCp. Finally, DOCp took place throughout the euphotic layer and across a wide range of irradiances. This suggested that photosynthate release by phytoplankton occurs as a background process of passive diffusion or leakage (Raven 1986), rather than representing an overflow mechanism when $\mathrm{C}$ fixation is high and nutrient supply is low (Wood \& Van Valen 1990).

In order to determine if the mechanisms and quantitative importance of phytoplankton DOCp observed in a coastal, eutrophic ecosystem are also applicable to a wider range of environments, it is critical to investigate DOCp under oligotrophic conditions. Low primary production rates $\left(\leq 0.5 \mathrm{~g} \mathrm{C} \mathrm{m}^{-2} \mathrm{~d}^{-1}\right)$ are common throughout most of the year over large expanses of the open ocean and are also characteristic of coastal and shelf seas during summer. The importance of oligotrophic regions (defined as those whose mean daily $\mathrm{C}$ fixation rate is $\leq 0.5 \mathrm{~g} \mathrm{C} \mathrm{m}^{-2} \mathrm{~d}^{-1}$ ) is illustrated by the fact that they account for $\sim 50 \%$ of global marine primary production (see Longhurst et al. 1995, their Table 1). It is therefore of interest to determine if DOCp in low-productivity waters occurs at a similar relative rate and through the same mechanisms as in productive waters. While some authors have reported high PER (>20 to $30 \%$ ) values in oligotrophic environments (Karl et al. 1998, Teira et al.
2001), these studies have not specifically addressed the mechanisms involved in the extracellular release of recent photosynthate.

The present study aims to determine the quantitative importance and likely mechanisms of DOCp in an oligotrophic environment, such as the Celtic Sea during the stratification period. In the Celtic Sea during summer, strong thermal stratification leads to nutrient depletion in the upper mixed layer, resulting in low $\left(\leq 0.5 \mathrm{~g} \mathrm{C} \mathrm{m}^{-2} \mathrm{~d}^{-1}\right)$ integrated rates of primary production (e.g. Joint \& Pomroy 1983, Joint et al. 1986). During a cruise to the Celtic Sea in July to August 2003, measurements of DOCp and POCp through the water column were combined with experiments aimed at determining the relationship between irradiance and PER, as well as the evolution of DOCp during $24 \mathrm{~h}$ light-dark cycles. Our ultimate objective was to test if our previous conclusions regarding DOCp in coastal, eutrophic waters (Marañón et al. 2004) are also valid for DOCp in open-sea, oligotrophic waters.

\section{MATERIALS AND METHODS}

Sampling. An oceanographic cruise to the Celtic Sea was conducted between 25 July and 14 August 2003 on board RRS 'James Clark Ross'. Most of the measurements reported here were obtained during repeated visits to 2 locations: a shelf station in the northern Celtic Sea (Stn CS3; 51 $28^{\prime}$ N, 06 $26^{\prime} \mathrm{W}$ ) and a shelfbreak station in the southern Celtic Sea (Stn CS2; $\left.48^{\circ} 33^{\prime} \mathrm{N}, 09^{\circ} 30^{\prime} \mathrm{W}\right)$. Three additional stations were sampled on a single occasion: Stn N9 $\left(48^{\circ} 17^{\prime} \mathrm{N}\right.$, $\left.10^{\circ} 13^{\prime} \mathrm{W}\right)$, Stn CS1 (50 $\left.52^{\prime} \mathrm{N}, 08^{\circ} 21^{\prime} \mathrm{W}\right)$ and Stn U2 $\left(49^{\circ} 14^{\prime} \mathrm{N}, 06^{\circ} 10^{\prime} \mathrm{W}\right)$. On each visit to the sampling locations, the vertical distributions of temperature and salinity were determined with a SeaBird 911 CTD probe. Vertical profiles of photosynthetically active irradiance (PAR) were obtained with a PAR sensor connected to a Chelsea Instrument Fastracka fluorometer. Water samples for chemical and biological measurements were collected, typically just before dawn, using a rosette equipped with 24 Teflon-coated bottles.

Inorganic nutrients and size-fractionated chlorophyll. The concentrations of nitrate, silicate and phosphate were determined on fresh samples that were analyzed, immediately after collection, on a Skalar autoanalyzer following standard methods (Grasshoff et al. 1999). For the determination of size-fractionated chlorophyll a (chl a) concentration, $250 \mathrm{ml}$ samples were filtered sequentially through polycarbonate filters of 20, 5, 2 and $0.2 \mu \mathrm{m}$ pore size, using low vacuum pressure $(<100 \mathrm{~mm} \mathrm{Hg})$. We determined the chl a concentration in the picophytoplankton ( 0.2 to $2 \mu \mathrm{m})$, small 
nanophytoplankton ( 2 to $5 \mu \mathrm{m}$ ), large nanophytoplankton $(5$ to $20 \mu \mathrm{m})$ and microphytoplankton (>20 $\mu \mathrm{m})$ size classes. Pigment extraction was carried out by placing the filters in $90 \%$ acetone for $12 \mathrm{~h}$ at $-20^{\circ} \mathrm{C}$. Chl a concentration was determined fluorometrically using a Turner Aquafluor fluorometer that had been calibrated with pure chl a (Sigma).

Photosynthetic production of POC and DOC. DOCp and POCp were determined at 4 to 5 depths in the euphotic zone by running simulated in situ (SIS), dawn-to-dusk incubations with the radioisotope ${ }^{14} \mathrm{C}$. Part of the DOC released during a dawn-to-dusk incubation may be consumed by bacteria, which means that our estimates of DOCp are probably closer to net production rates. In most cases, sampling took place just before dawn, and incubations were started within 30 min. Logistical constraints, however, forced us to make 3 exceptions to this protocol. The first sampling of Stn CS2 and the sampling of Stn U2 took place in the evening. In these cases, seawater samples for productivity measurements were stored in the dark inside a refrigerated room, until the experiments started the next morning. Biological sampling at Stn N9 took place at noon, and the productivity experiments were conducted on the same day from 12:30 h until dusk. Hourly productivity rates at this station were converted to daily rates by multiplying them by the duration of the photoperiod.

We used a deck incubator equipped with a set of blue and neutral density filters that reproduced 8 light levels from 100 to $1 \%$ of the incident irradiance $\left(E_{0}\right)$. Taking into account the vertical distribution of PAR at each site, we incubated the samples at the approximate PAR extinction level that was recorded at the sampling depth. Samples from the upper layer were kept inside an incubator refrigerated with running water pumped from the surface ( $7 \mathrm{~m}$ depth). Samples from the thermocline and below were kept inside an incubator connected to a refrigerator, which maintained the temperature within $2{ }^{\circ} \mathrm{C}$ of in situ temperature.

The method used to simultaneously measure DOCp and POCp is described in detail in Marañón et al. (2004). For each sampling depth, 3 light and 1 dark acid-washed, Pyrex glass bottles (36 $\mathrm{ml}$ in volume) were filled with the sample and inoculated with $15 \mu \mathrm{Ci}$ (555 KBq) of $\mathrm{NaH}^{14} \mathrm{CO}_{3}$. At the end of the incubation, aliquots from each bottle were filtered through $0.2 \mu \mathrm{m}$ polycarbonate filters, using low vacuum pressures (<100 mm Hg). Filtration-induced cell breakage can be a source of error in DOCp measurements, sometimes giving rise to inconsistencies between the sum of DOCp and POCp and total primary production (TOCp) as determined in unfiltered samples (Lignell 1992). We have tested this possibility in previous experiments with widely differing types of phytoplankton assem- blages during a whole annual cycle. It was concluded that, with our experimental procedure, filtration did not cause cell breakage, given that the measurements of TOCp in unfractionated samples coincided with the sum of DOCp and POCp (Marañón et al. 2004, their Fig. 4C). After being acidified to $\mathrm{pH} \sim 2$ with $100 \mu \mathrm{l}$ of $18.5 \% \mathrm{HCl}$, filtrates were kept for $12 \mathrm{~h}$ in open scintillation vials placed on an orbital shaker. Then, $15 \mathrm{ml}$ of a high sample capacity scintillation cocktail was added to each filtrate. The inorganic ${ }^{14} \mathrm{C}$ present in the filters was removed by exposing them to concentrated $\mathrm{HCl}$ fumes for $12 \mathrm{~h}$. Filters were then placed in scintillation vials to which $4 \mathrm{ml}$ of scintillation cocktail was added.

The radioactivity of each sample (disintegrations per minute, DPM) was determined on a Beckman LS6000 scintillation counter that used an internal standard for quenching correction. Dark-bottle DPMs were subtracted from the light-bottle DPMs in order to calculate the rates of DOCp and POCp. Typically, DPM counts in the dark bottle were approximately 10 to $20 \%$ of the DPM counts in the light bottle. We used a constant value of $25700 \mathrm{mg} \mathrm{C} \mathrm{m}^{-3}$ for the concentration of dissolved inorganic carbon (DIC) and a value of 1.05 for the isotopic discrimination factor. For all pooled determinations of POCp $(\mathrm{n}=52)$ and DOCp $(\mathrm{n}=52)$, the average coefficients of variation were 11 and $14 \%$, respectively.

Size-fractionated primary production. We determined the vertical distribution of particulate, size-fractionated primary production in the picophytoplankton, small nanophytoplankton, large nanophytoplankton and microphytoplankton size classes. Parallel SIS experiments were conducted with seawater samples collected from 4 to 6 depths in the euphotic layer. For each depth, 3 light and 1 dark acid-washed, polystyrene bottles (100 $\mathrm{ml}$ in volume) were filled with the sample, inoculated with $10 \mu \mathrm{Ci}(370 \mathrm{KBq})$ of $\mathrm{NaH}^{14} \mathrm{CO}_{3}$, and incubated as previously explained for POCp and DOCp measurements. At the end of the incubation, samples were sequentially filtered through $20,5,2$ and $0.2 \mu \mathrm{m}$ polycarbonate filters, using low vacuum pressure (<100 mmHg). Sample processing and production calculations were done as previously described for POC samples. Total production rate for the whole phytoplankton community was calculated as the sum of the primary production rate in each size class.

Photosynthesis-irradiance experiments. On several occasions during the cruise, we collected additional water samples from either the surface or the subsurface chl a maximum (SCM) in order to conduct photosynthesis-irradiance $(\mathrm{P}-\mathrm{E})$ experiments and determine the relationship between irradiance and PER. A total of 12 acid-washed, polystyrene bottles $(100 \mathrm{ml}$ in volume) were filled with seawater and spiked with $10 \mu \mathrm{Ci}(370 \mathrm{KBq})$ of $\mathrm{NaH}^{14} \mathrm{CO}_{3}$. Samples were incu- 
bated for $2 \mathrm{~h}$ in a linear incubator equipped with a $100 \mathrm{~W}$ halogen lamp and calibrated to provide a PAR range from 0 to $2000 \mu \mathrm{mol} \mathrm{m} \mathrm{m}^{-2} \mathrm{~s}^{-1}$. The incubator was cooled with water pumped from the sea surface. Filtration, manipulation of filters and filtrates, scintillation counting and calculations of primary production were all carried out as described before for the vertical profiles of POCp and DOCp.

Kinetics of DOCp and POCp. In order to monitor the evolution of DOCp and POCp during a $24 \mathrm{~h}$ light-dark cycle, we carried out a time-series experiment with SCM seawater collected at Stn CS3 on 5 August 2003 (JD217); 24 Pyrex bottles (36 $\mathrm{ml}$ in volume) were inoculated with $15 \mu \mathrm{Ci}(555 \mathrm{KBq})$ of $\mathrm{NaH}^{14} \mathrm{CO}_{3}$ and kept in the deck incubator under an irradiance equal to $20 \%$ of $E_{0}$. At each sampling time, 2 bottles were processed for the determination of POCp and DOCp, as described before. The DPMs measured in the time zero samples were subtracted from the DPMs measured in the samples from each subsequent sampling time.

\section{RESULTS}

\section{Temperature and nutrient concentration}

All stations included in the present study were characterized by surface temperatures in the range from 16 to $18.5^{\circ} \mathrm{C}$ and the presence of thermal, vertical stratification, although the depth and steepness of the thermocline varied between locations (Fig. 1). At Stn CS3, the upper mixed layer was shallow (10 to $15 \mathrm{~m}$ ) and the thermocline was relatively steep. Stns C1 and U2 showed stronger vertical stratification, with an upper mixed layer that extended down to 20-25 m. Stns CS2 and N9 were characterized by the presence of an eroded, relatively weak thermocline that extended along $>50 \mathrm{~m}$.

The concentrations of all 3 analyzed nutrients (nitrate, phosphate and silicate) covaried $\left(\mathrm{r}^{2}>0.8\right.$ in all paired correlations). Phosphate and silicate concentrations in surface waters were very low $(<0.1$ and $<1 \mu \mathrm{M}$, respectively). In general, nitrate was undetectable $(<0.05 \mu \mathrm{M})$ in surface waters (Fig. 1). Nitrate concentrations increased sharply below the thermocline, typically reaching values of $>5$ to $6 \mu \mathrm{M}$ at depths $>50 \mathrm{~m}$, where phosphate and silicate concentrations were $>0.3$ and $>3 \mu \mathrm{M}$, respectively.

\section{Size-fractionated chl a concentration}

Surface chl a concentrations were low throughout the cruise, taking values in the range from 0.3 to $0.8 \mathrm{mg} \mathrm{m}^{-3}$ (Fig. 2). Stn CS3 was characterized by the presence of a marked SCM, which was located at 20 to $30 \mathrm{~m}$ depth. The SCM was deeper at Stn CS1, reflecting the presence of a deeper thermocline. Bearing in mind phytoplankton photoacclimation, it is possible that the observed SCM was partially caused by an increase in the cellular chl a content under low irradiance, and not only the result of increased biomass or cell numbers in the vicinity of the thermocline. Near the shelf-break (Stns CS2 and N9), where thermal
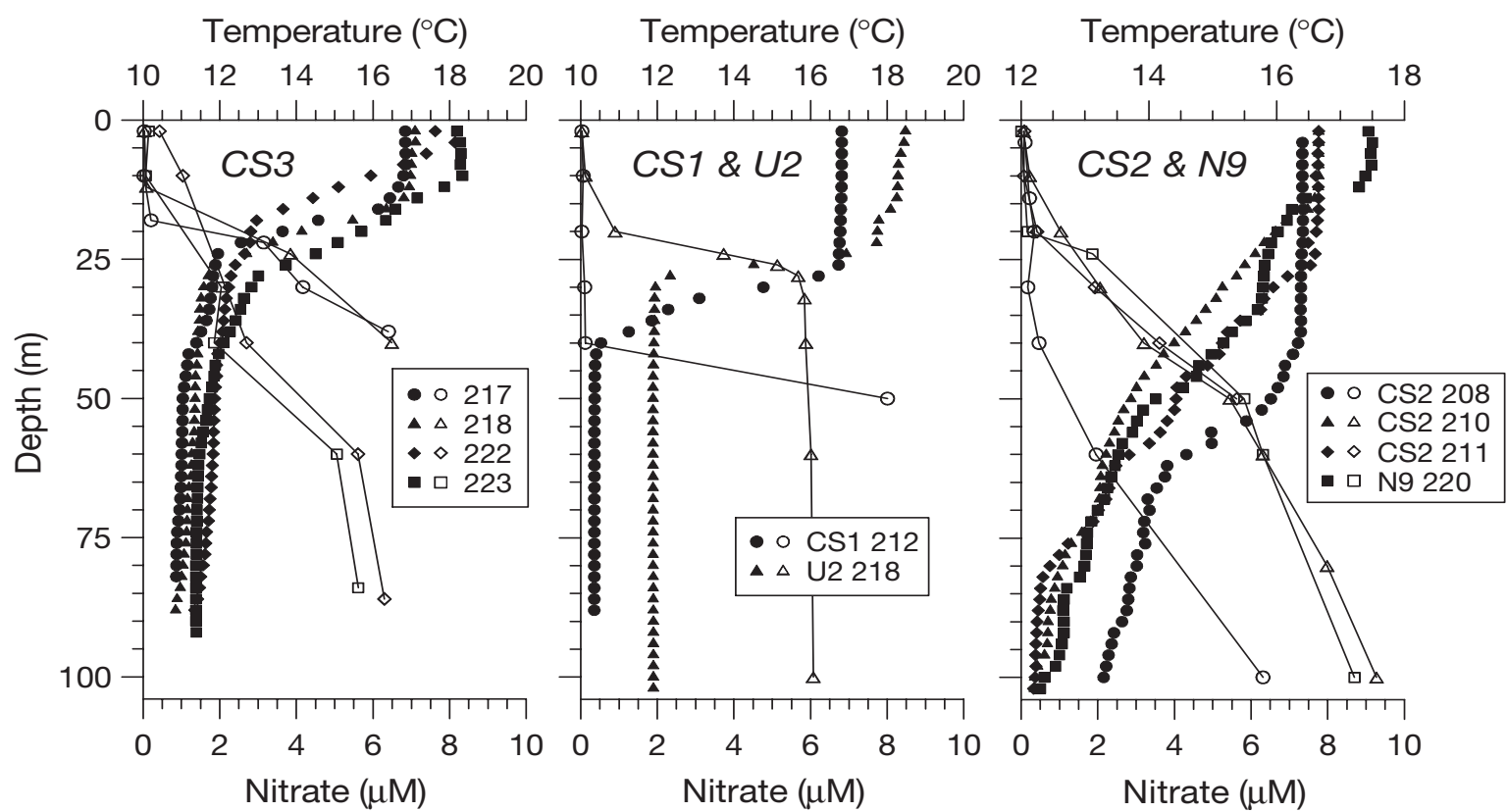

Fig. 1. Vertical profiles of temperature (closed symbols, ${ }^{\circ} \mathrm{C}$ ) and nitrate concentration (open symbols, $\mu \mathrm{M}$ ) at sampling Stns CS3, CS1 \& U2, and CS2 \& N9. Numbers after station labels indicate the sampling date as day of the year 


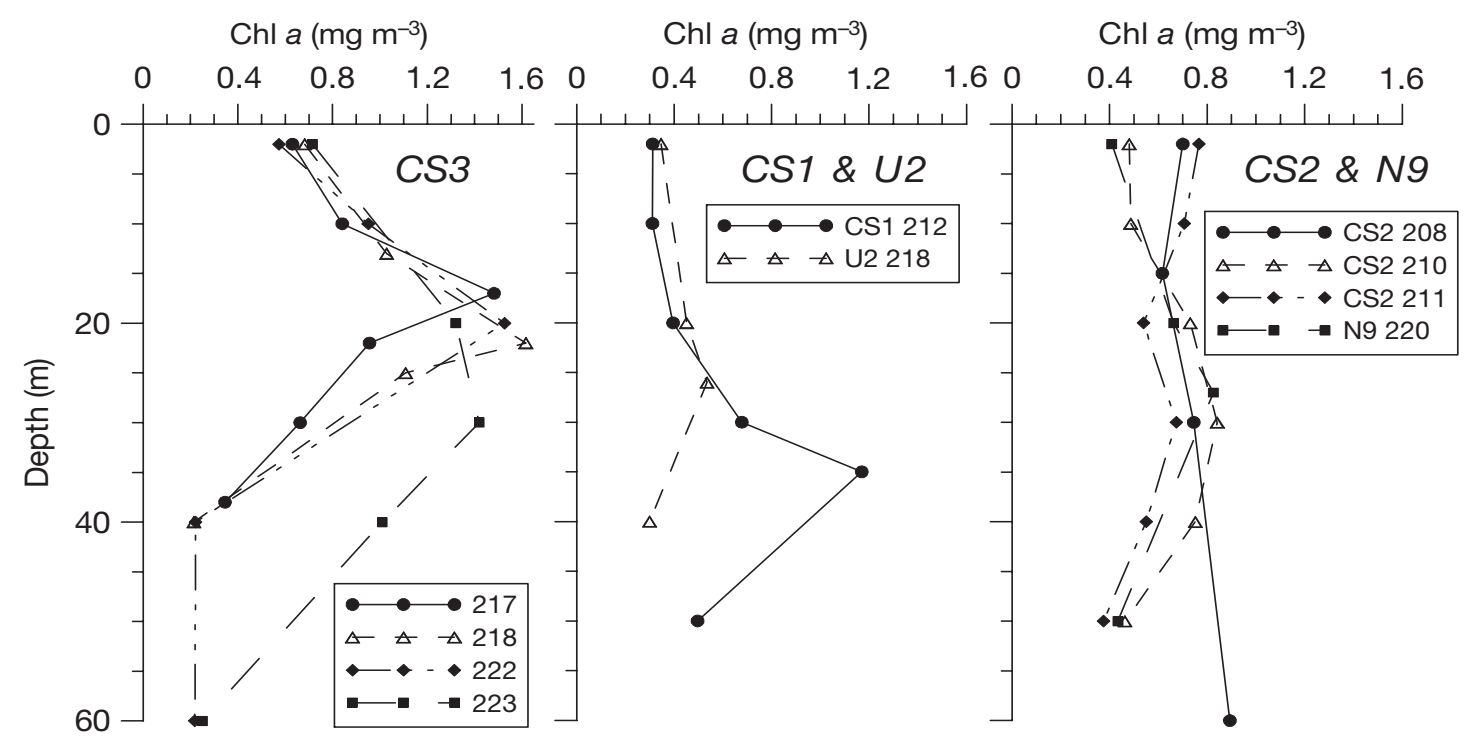

Fig. 2. As for Fig. 1, but for chlorophyll a concentration $\left(\mathrm{mg} \mathrm{m}^{-3}\right)$

stratification was weaker, we observed little vertical variability in chl a concentrations, and, when present, the SCM represented only a modest increase in comparison with surface concentrations.

Given that the partitioning of the chl a concentration among different size classes was relatively constant with depth throughout the cruise, the vertically integrated concentrations are adequate to describe the variability in the size structure of phytoplankton biomass (Table 1). At the stations with a higher degree of vertical stratification (CS3, CS1 and U2), picophytoplankton $(0.2-2 \mu \mathrm{m})$ were the dominant size fraction, accounting for 35 to $40 \%$ of total chl a. Microphytoplankton $(>20 \mu \mathrm{m})$ contributed only 6 to $12 \%$ of total chl $a$ at these stations, while both small $(2-5 \mu \mathrm{m})$ and large $(5-20 \mu \mathrm{m})$ nanophytoplankton accounted for around 25 to $30 \%$ of total chl a. At Stns CS2 and N9, the distribution of chl a among size fractions was more balanced, with the pico- and microphytoplankton size classes showing the highest relative contributions (around $30 \%$ ). For all pooled stations in our survey, the mean $( \pm 1 \mathrm{SE})$ contribution of picophytoplankton and small nanophytoplankton to total, integrated chl a concentration was $58 \pm 3 \%$.

\section{Production of POC and DOC}

Typical surface POCp rates during our study, calculated as the sum of primary production in each size fraction (see 'Materials and methods'), were in the range from 5 to $15 \mathrm{mg} \mathrm{C} \mathrm{m}^{-3} \mathrm{~d}^{-1}$ (Fig. 3). In most cases,

Table 1. Mean values $( \pm 1 \mathrm{SE})$ of euphotic layer-integrated chlorophyll a concentration $\left(\mathrm{chl} a_{1} \mathrm{mg} \mathrm{m}^{-2}\right)$ and particulate primary production rate (POCp, $\mathrm{mg} \mathrm{C} \mathrm{m}^{-2} \mathrm{~d}^{-1}$ ) at sampling Stns CS3, CS1 \& U2, and CS2 \& N9. Also indicated are the relative contributions of each phytoplankton size class $(0.2-2,2-5,5-20$ and $>20 \mu \mathrm{m})$ to total, euphotic layer-integrated chl $a$ concentration and POCp, as well as the euphotic layer-integrated percentage of extracellular release (PER), calculated as $100 \times \mathrm{DOCp} /(\mathrm{DOCp}+\mathrm{POCp}$ ). Integrated POCp was calculated as the sum of integrated primary production in each size class (see 'Materials and methods')

\begin{tabular}{|c|c|c|c|c|c|c|c|c|c|c|c|}
\hline \multirow{2}{*}{ Stns } & \multirow{2}{*}{ Total chl a } & \multicolumn{4}{|c|}{$-\mathrm{Chl} a(\%)-$} & \multirow{2}{*}{ Total POCp } & \multicolumn{4}{|c|}{$\amalg_{\text {POCp }(\%)}-$} & \multirow{2}{*}{ PER $(\%)$} \\
\hline & & $0.2-2$ & $2-5$ & $5-20$ & $>20$ & & $0.2-2$ & $2-5$ & $5-20$ & $>20$ & \\
\hline CS3 & $\begin{array}{l}42.4 \\
(5.8)\end{array}$ & $\begin{array}{l}34.6 \\
(1.1)\end{array}$ & $\begin{array}{l}29.4 \\
(0.4)\end{array}$ & $\begin{array}{l}26.9 \\
(2.5)\end{array}$ & $\begin{array}{c}5.7 \\
(0.4)\end{array}$ & $\begin{array}{c}574 \\
(127)\end{array}$ & $\begin{array}{l}50.7 \\
(1.9)\end{array}$ & $\begin{array}{l}17.2 \\
(1.3)\end{array}$ & $\begin{array}{l}28.1 \\
(1.3)\end{array}$ & $\begin{array}{c}4.0 \\
(0.2)\end{array}$ & $\begin{array}{l}22.6 \\
(1.8)\end{array}$ \\
\hline $\mathrm{CS} 1 \& \mathrm{U} 2$ & $\begin{array}{l}23.0 \\
(6.2)\end{array}$ & $\begin{array}{l}39.4 \\
(6.0)\end{array}$ & $\begin{array}{l}24.0 \\
(3.1)\end{array}$ & $\begin{array}{l}23.7 \\
(6.0)\end{array}$ & $\begin{array}{l}11.9 \\
(2.7)\end{array}$ & $\begin{array}{l}331 \\
(20)\end{array}$ & $\begin{array}{l}56.7 \\
(6.1)\end{array}$ & $\begin{array}{l}17.1 \\
(2.6)\end{array}$ & $\begin{array}{l}21.5 \\
(8.6)\end{array}$ & $\begin{array}{c}4.7 \\
(0.2)\end{array}$ & $\begin{array}{l}28.5 \\
(4.2)\end{array}$ \\
\hline CS2 \& N9 & $\begin{array}{l}34.6 \\
(3.4)\end{array}$ & $\begin{array}{l}27.6 \\
(2.8)\end{array}$ & $\begin{array}{l}21.2 \\
(0.7)\end{array}$ & $\begin{array}{l}17.2 \\
(0.8)\end{array}$ & $\begin{array}{l}33.7 \\
(3.7)\end{array}$ & $\begin{array}{l}536 \\
(70)\end{array}$ & $\begin{array}{l}23.9 \\
(4.2)\end{array}$ & $\begin{array}{l}26.4 \\
(1.9)\end{array}$ & $\begin{array}{l}15.9 \\
(1.0)\end{array}$ & $\begin{array}{l}33.8 \\
(3.8)\end{array}$ & $\begin{array}{l}18.7 \\
(1.8)\end{array}$ \\
\hline
\end{tabular}




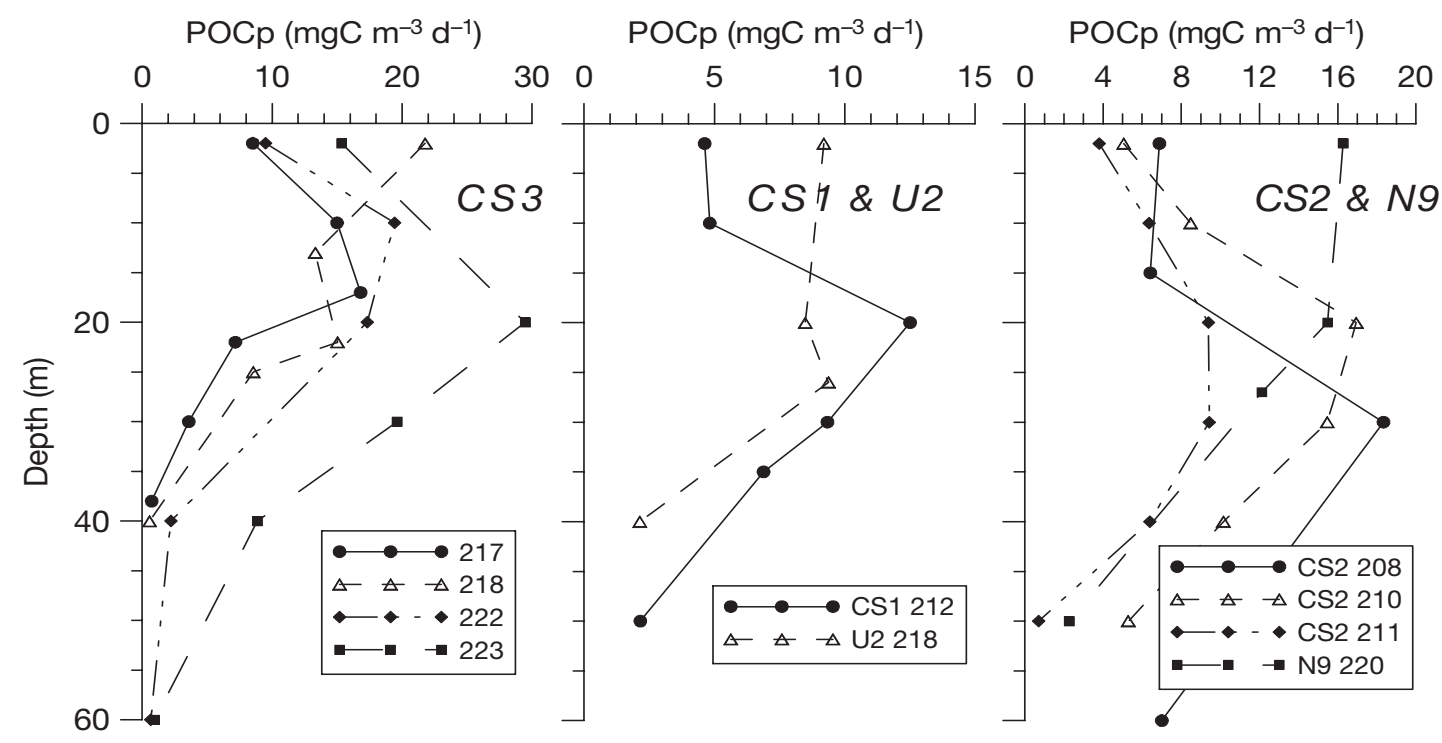

Fig. 3. As for Fig. 1, but for particulate organic carbon production (POCp, $\mathrm{mg} \mathrm{C} \mathrm{m}^{-3} \mathrm{~d}^{-1}$ ). POCp was calculated as the sum of primary production in each size class

the vertical profiles were characterized by the presence of a subsurface maximum at 10 to $30 \mathrm{~m}$ and a marked decrease towards the base of the euphotic layer (Fig. 3). The POCp to chl a ratio showed a clear decreasing trend with depth (data not shown). The mean $( \pm 1 \mathrm{SE})$, euphotic layer-integrated POCp at CS3 was $574 \pm 127 \mathrm{mg} \mathrm{C} \mathrm{m}^{-2} \mathrm{~d}^{-1}$ (Table 1). At Stns CS1 and $\mathrm{U} 2$, POCp was lower, taking integrated values around $300 \mathrm{mg} \mathrm{C} \mathrm{m}{ }^{-2} \mathrm{~d}^{-1}$. Mean integrated POCp at CS2 and $\mathrm{N} 9$ was $536 \pm 70 \mathrm{mg} \mathrm{C} \mathrm{m}{ }^{-2} \mathrm{~d}^{-1}$ (Table 1). For the whole study, the mean, euphotic layer-integrated POCp was $510 \pm 61 \mathrm{mg} \mathrm{C} \mathrm{m}^{-2} \mathrm{~d}^{-1}(\mathrm{n}=10)$, which agrees well with previous estimates reported for the same region during summer (Joint \& Pomroy 1983, Joint et al. 1986).

DOCp showed less vertical variability than POCp, and typical rates were in the range from 1 to $3 \mathrm{mg} \mathrm{C}$ $\mathrm{m}^{-3} \mathrm{~d}^{-1}$ (Fig. 4). Except at Stn U2, DOCp decreased only moderately with increasing depth, and in many cases it remained relatively constant over the entire euphotic layer. Unlike the POCp to chl a ratio, the DOCp to chl a ratio did not show any trend with depth. Integrated rates of DOCp were $111 \pm 21,110 \pm 35,39$, $76,79 \pm 18$ and $208 \mathrm{mg} \mathrm{C} \mathrm{m}^{-2} \mathrm{~d}^{-1}$ at Stns CS3, CS1, U2, CS2 and N9, respectively. There was a close covaria-

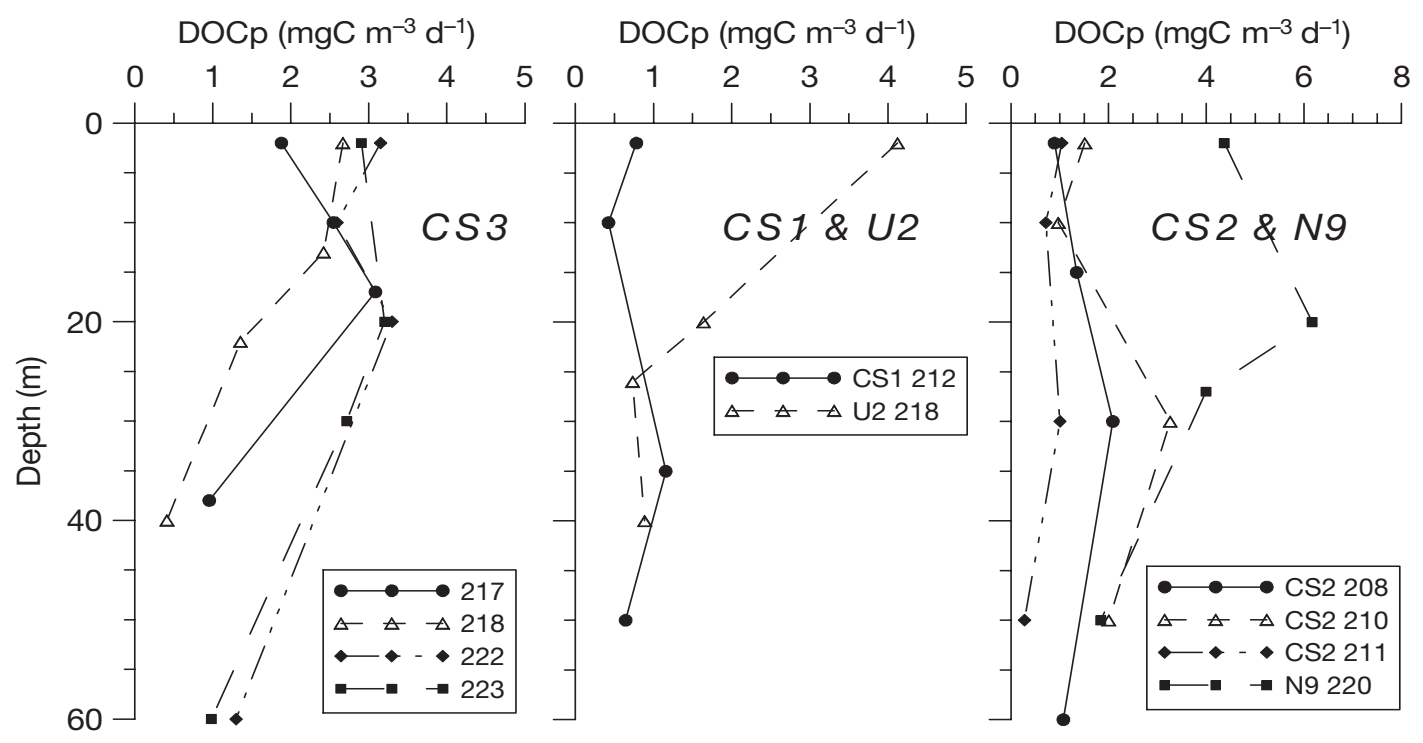

Fig. 4. As for Fig. 1, but for dissolved organic carbon production (DOCp, $\mathrm{mg} \mathrm{C} \mathrm{m}^{-3} \mathrm{~d}^{-1}$ ) 
tion between the euphotic layer-integrated rates of POCp and DOCp. Integrated DOCp could be expressed as a linear function of integrated POCp $\left(\mathrm{DOCp}=0.20 \times\right.$ POCp $\left.+20.10, \mathrm{r}^{2}=0.89, \mathrm{n}=10\right)$. The high determination coefficient of this linear regression indicates that most of the variability in DOCp was explained by the changes in POCp.

The vertical variability in PER [calculated as DOCp/(DOCp + POCp)] was mainly due to changes in POCp. In most profiles, the highest PER values ( $>40$ to $50 \%$ ) were measured at the bottom of the euphotic layer, while the lowest ones (10 to 20\%) were measured at intermediate depths, coinciding with the peak in POCp (Fig. 5). The vertically integrated PER values were relatively constant throughout the study, and took average values of $23 \pm 2 \%$ at Stn CS3, $28 \pm 4 \%$ at Stns CS1 and U2, and $19 \pm 2 \%$ at Stns CS2 and N9 (Table 1). The mean, integrated PER value for all profiles $(n=10)$ in our study was $22 \pm 2 \%$.

\section{Size-fractionated primary production}

As was the case with size-fractionated chl a concentration, we did not observe any marked vertical variability in size-fractionated, particulate primary production. The partitioning of primary production among the different size classes was similar at the 3 most stratified stations (CS3, CS1 and U2) and was characterized by a marked dominance of the picophytoplankton, which accounted for $>50 \%$ of total production (Table 1). By contrast, microphytoplankton accounted only for $<5 \%$ of total production at these sites. At Stns CS2 and N9, which showed a smaller degree of ther- mal stratification, the distribution of primary production among the different size classes was more balanced. For the whole study, picophytoplankton and small nanophytoplankton together accounted for $63 \pm$ $4 \%$ of total primary production. Previous studies have reported that the $<5 \mu \mathrm{m}$ size fraction accounts for 65 to $75 \%$ of total C fixation in the Celtic Sea during summer (Joint \& Pomroy 1983, Joint et al. 1986).

\section{Irradiance and PER}

In all 3 experiments performed to determine the relationship between irradiance and DOCp, PER increased markedly at low irradiances (Fig. 6). This increase occurred as a result of the fact that DOCp was relatively constant across the whole irradiance range, while POCp decreased markedly at subsaturating irradiances.

\section{Kinetics of DOC and POC production}

A time-course experiment to monitor POCp and DOCp by SCM phytoplankton during a dawn-to-dawn cycle was conducted at Stn CS3 on the 217th day of the year. Both POCp and DOCp increased linearly during the light hours (Fig. 7). POCp stopped immediately after dusk, while DOCp continued for another 2 to $3 \mathrm{~h}$ and then stopped as well. During the dark hours, POCp decreased slightly, which was likely due to the respiratory loss of labeled organic carbon. The results of this time-course experiment show that DOCp was dependent on light availability and closely linked to POCp.

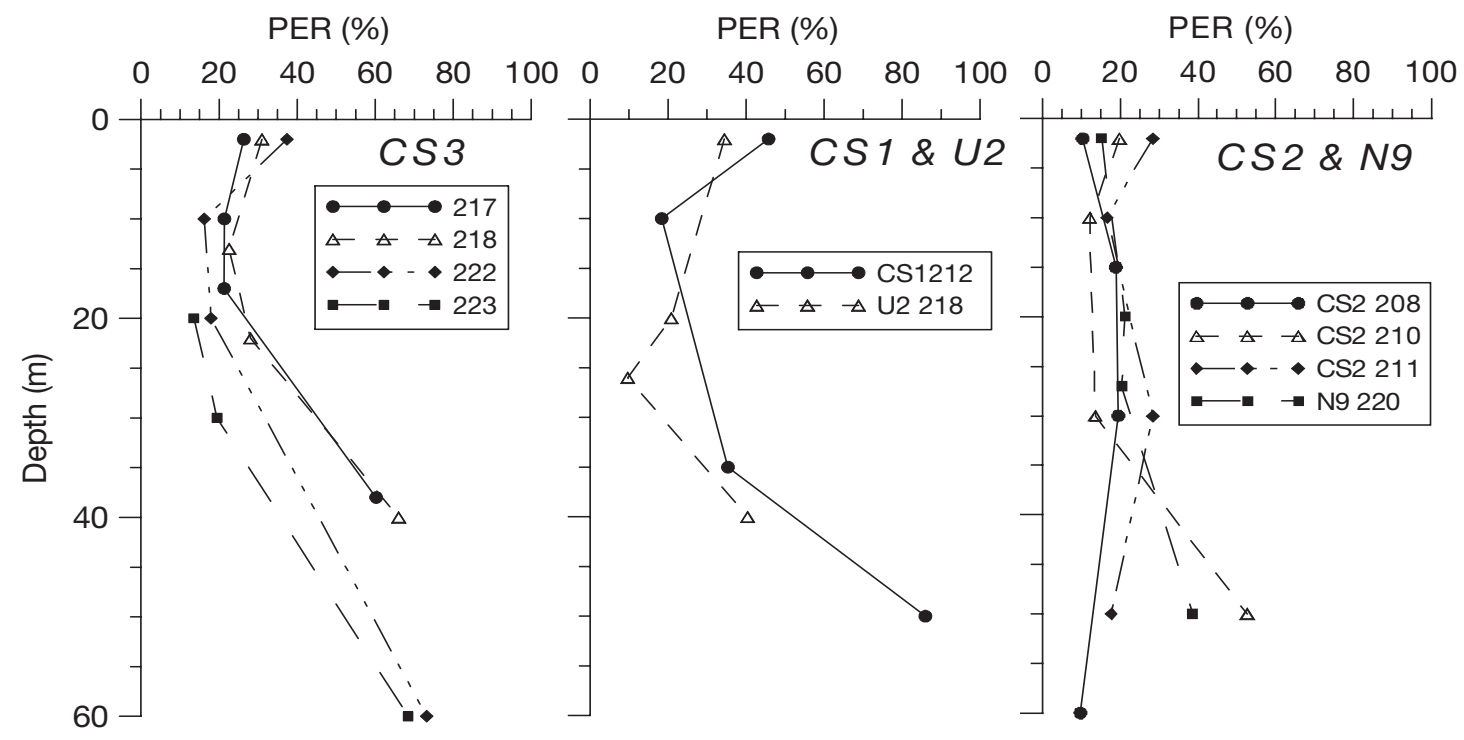

Fig. 5. As for Fig. 1, but for percentage of extracellular release (PER) 


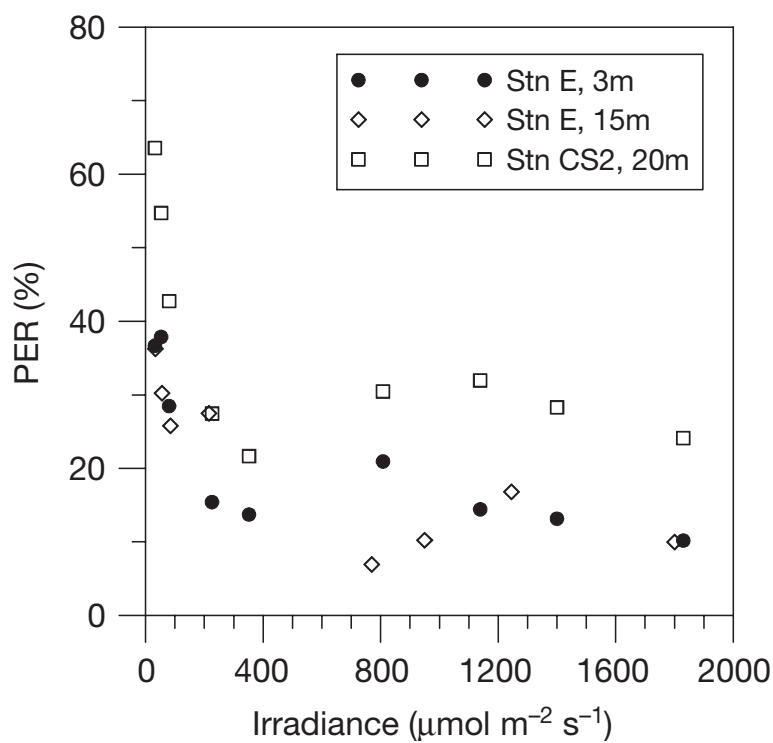

Fig. 6. Relationship between irradiance and percentage of extracellular release (PER), determined in P-E experiments with phytoplankton assemblages collected at Stns PML E and CS2

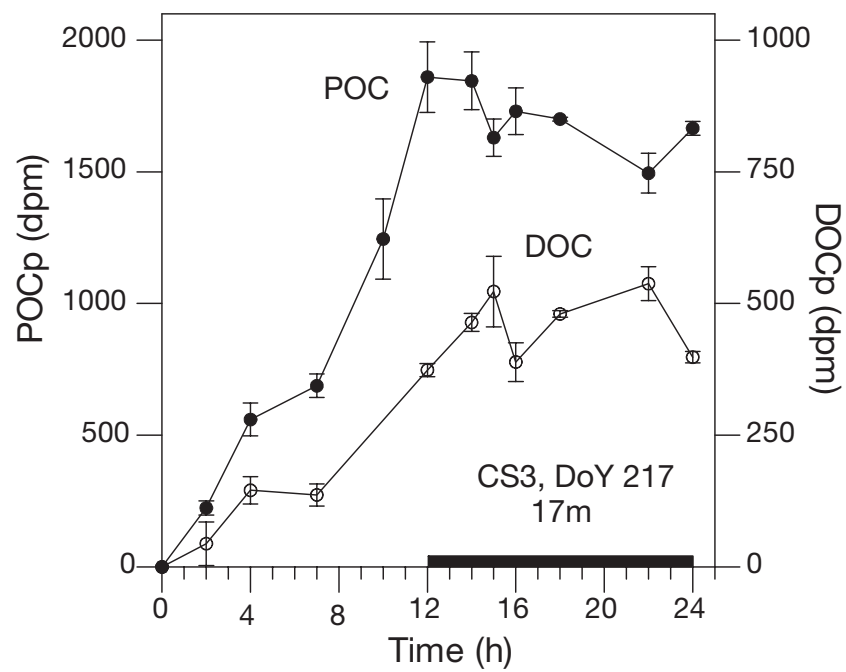

Fig. 7. Time-course experiment of particulate organic carbon production (POCp) and dissolved organic carbon production (DOCp) by phytoplankton from the subsurface chl a maximum (depth $=15 \mathrm{~m}$ ) during a natural day-night cycle at Stn $\mathrm{CS} 3$ on the 217th day of the year (DoY). Bars indicate $\pm 1 \mathrm{SD}$

\section{DISCUSSION}

\section{Mechanisms of DOC production}

Microzooplankton sloppy feeding, excretion and egestion may be important DOC sources, particularly in oligotrophic ecosystems, where grazing by protists is the main loss factor for phytoplankton (Banse 1995,
Nagata 2000). Experimental evidence suggests that DOC release due to these processes can even exceed that due to direct phytoplankton production (Strom et al. 1997). However, when it comes to the extracellular release of recently photosynthesized compounds, as determined, for instance, by the ${ }^{14} \mathrm{C}$ uptake technique, the role of microzooplankton seems less important. Our time-series experiment of DOCp over $24 \mathrm{~h}$ clearly showed that DOC accumulation began immediately after the start of the experiment and stopped after the light period. The same kinetics of DOCp were obtained by Mague et al. (1980) in the Gulf of Maine and by Karl et al. (1998) in the North Pacific subtropical gyre. If grazing-related processes were the main mechanism of $\mathrm{DO}^{14} \mathrm{C}$ release, we should have observed a lag between POCp and DOCp at the beginning of the experiment and, more importantly, $\mathrm{DO}^{14} \mathrm{C}$ accumulation should have continued during the dark period. It is unlikely that DOC continued to be produced during the dark but did not accumulate as a result of bacterial uptake. Firstly, there is no reason to expect that bacterial uptake of DOC should suddenly increase at the end of the photoperiod. Secondly, there is no reason to expect that, even if bacterial DOC uptake did increase in the dark, its rate should match exactly the rate of DOCp so that $\mathrm{DO}^{14} \mathrm{C}$ concentration remained constant. We interpret the observed kinetics of DOCp as an indication that the release of recently fixed photosynthate occurs through purely physiological mechanisms, not mediated by trophic processes. It is likely that the released compounds belong to a pool of recently synthesized molecules with a high turnover rate and whose intracellular abundance decreases quickly once photosynthesis stops. This would explain the lack of $\mathrm{DO}^{14} \mathrm{C}$ accumulation during the dark. Finally, the results of the P-E experiments are also consistent with the view that direct release from intact cells is the main pathway for DOCp. Across a wide irradiance range, DOCp remained relatively constant, whereas POCp showed a marked light-dependence. If photosynthate release were mainly caused by indirect mechanisms involving cell breakage and/or zooplankton grazing, we should expect DOCp to increase with irradiance in the same way as POCp.

Direct release of recent photosynthate by intact cells may represent an overflow mechanism to compensate for excessive $\mathrm{C}$ fixation under conditions of limited nutrient availability (Wood \& Van Valen 1990), or, alternatively, it may occur simply through passive diffusion of small metabolites across the cell membrane (Bjørnsen 1988). The first mechanism would represent a strategy of phytoplankton to cope with particular growth conditions, characterized by an uncoupling between energy and nutrient availability. An example of this process is given by the enhanced release 
of extracellular polysaccharides observed during the decline of some diatom blooms (Barlow 1982, Norrman et al. 1995). By contrast, the second mechanism reflects a continuous background process of leakage of metabolites from the intracellular medium, which is likely to occur at a relatively constant biomass-specific rate, irrespective of phytoplankton growth conditions and physiological state.

During our study, we observed similar levels of chl a specific DOCp in well-illuminated surface waters, where nutrients were depleted, and near the bottom of the euphotic layer, where irradiance was low and nutrients were plentiful. The highest PER values were typically measured in the deepest samples. Importantly, the DOCp rates that were measured throughout the water column could not be the result of dark uptake processes, contamination of ${ }^{14} \mathrm{C}$ stocks, or incomplete removal of inorganic ${ }^{14} \mathrm{C}$ from the filtrates, given that the potential interference of all these processes was eliminated by subtracting dark-bottle DPMs from light-bottle DPMs. If overflow had been the main mechanism involved, we should have found significant levels of DOCp only in surface waters, under conditions of high irradiance and low nutrient supply. Furthermore, the results of the $\mathrm{P}-\mathrm{E}$ experiments showed that DOCp was relatively constant throughout a wide range of irradiances, giving way to a marked PER increase under low light, a pattern that has been reported before, both for cultured (Zlotnik \& Dubinsky 1989) and natural (Morán \& Estrada 2001) phytoplankton populations. All these observations support the view that passive diffusion, rather than overflow, was likely to be the main mechanism of DOC release in the Celtic Sea during the summer stratification period.

\section{DOC production in eutrophic versus oligotrophic ecosystems}

Our measurements of DOCp in an oligotrophic environment such as the Celtic Sea, combined with the results of our previous investigations of DOCp in a coastal, eutrophic ecosystem (Marañón et al. 2004), allow us to assess if the quantitative importance of DOCp is the same in widely different types of phytoplankton communities and across a wide productivity range. During our study, integrated PER averaged $22 \pm$ $2 \%$, which compares well with the mean value of $15 \%$ obtained by Joint \& Pomroy (1983) in the central Celtic Sea during July to August 1982. Karl et al. (1998) reported integrated PER values around 30\% for the North Pacific subtropical gyre, while Teira et al. (2001) obtained an average PER value of $23 \%$ for the eastern North Atlantic subtropical gyre. Considering the methodological differences involved, there is relatively good agreement between the various measurements of DOCp, and all the evidence suggests that the release of recent photosynthate in dissolved form accounts for a substantial fraction of total primary production in oligotrophic ecosystems.

It is interesting to compare our measurements of phytoplankton biomass, size-structure and DOCp in the Celtic Sea during summer oligotrophic conditions with previous observations in a highly productive ecosystem such as the Ría de Vigo (Marañón et al. 2004). The relative importance of DOCp is similar in the 2 systems (Fig. 8): mean integrated PER was $22 \%$ in the Celtic Sea and 19\% in the Ría de Vigo. However, these systems differed widely in terms of mean values of various properties such as chl a concentration ( $70 \mathrm{mg} \mathrm{m}^{-2}$ in the Ría de Vigo versus $35 \mathrm{mg} \mathrm{m}^{-2}$ in the Celtic Sea), contribution of small cells $(<5 \mu \mathrm{m})$ to total chl a concentration (18 versus 58\%), contribution of small cells to total POCp (12 versus 63\%), POCp (3700 versus $500 \mathrm{mg} \mathrm{C} \mathrm{m}^{-2} \mathrm{~d}^{-1}$ ) and DOCp (820 versus $100 \mathrm{mg} \mathrm{C} \mathrm{m}^{-2} \mathrm{~d}^{-1}$ ) (Fig. 8). Nutrient availability was also very different in the 2 environments: surface nitrate concentration averaged $2.2 \mu \mathrm{M}$ in the Ría de Vigo, compared with $0.11 \mu \mathrm{M}$ in the Celtic Sea. Not only the relative importance of DOCp was similar in the 2 systems, but the underlying processes involved in DOC release were likely to be the same as well. In our study of the Ría de Vigo, we also found that a purely physiological mechanism (i.e. not mediated by trophic processes) of passive diffusion was the main mechanism explaining the release of DOC by normally growing cells (Marañón et al. 2004). These observations do not support the tenet that different processes account for DOCp in eutrophic versus oligotrophic environments (Sharp 1977, Teira et al. 2001).

We observed a remarkable continuity in the significance of DOCp from eutrophic to oligotrophic conditions. This can be illustrated by plotting together all measurements of integrated DOCp and POCp, obtained in the Ría de Vigo and the Celtic Sea (Fig. 9). All 35 observations could be fitted to a single linear model expressed by the equation $\log (\mathrm{DOCp})=0.96 \times \log$ (POCp) $-0.51\left(\mathrm{r}^{2}=0.90, \mathrm{p}<0.001\right)$. The slope of this regression was not significantly different from 1 , which means that PER was relatively constant at $20 \%$ within a productivity range from $<100$ to $>15000 \mathrm{mg} \mathrm{C} \mathrm{m}^{-2}$ $\mathrm{d}^{-1}$. This constancy in PER across a wide productivity range was also reported by Baines \& Pace (1991), who reviewed the literature for DOCp measurements in lakes and estuaries. However, these authors found a lower mean PER (13\%), which may reflect a fundamental difference in DOCp between lakes and estuaries and the open sea. The discrepancy can also be due to a methodological problem, given that many of the DOCp measurements reviewed by Baines \& Pace 

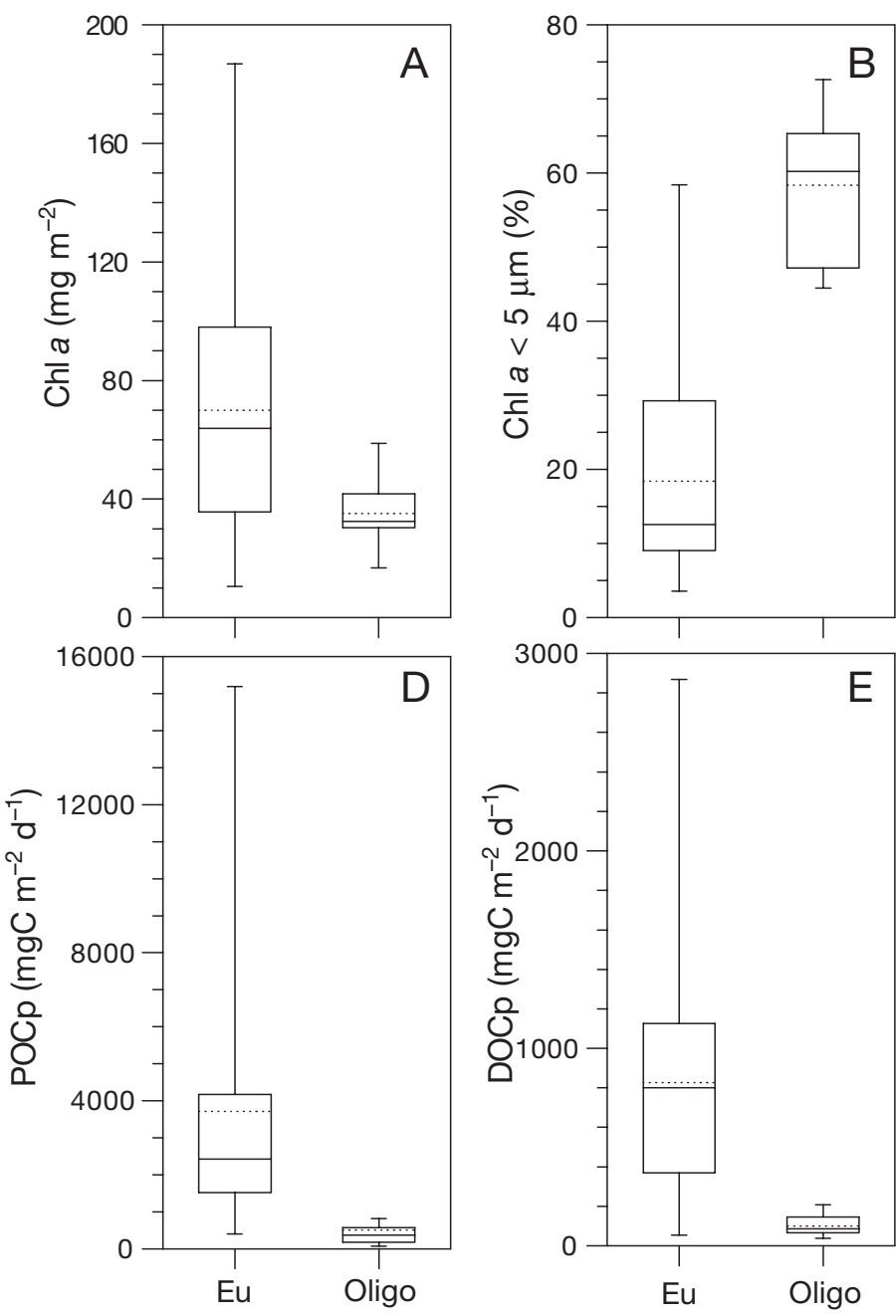

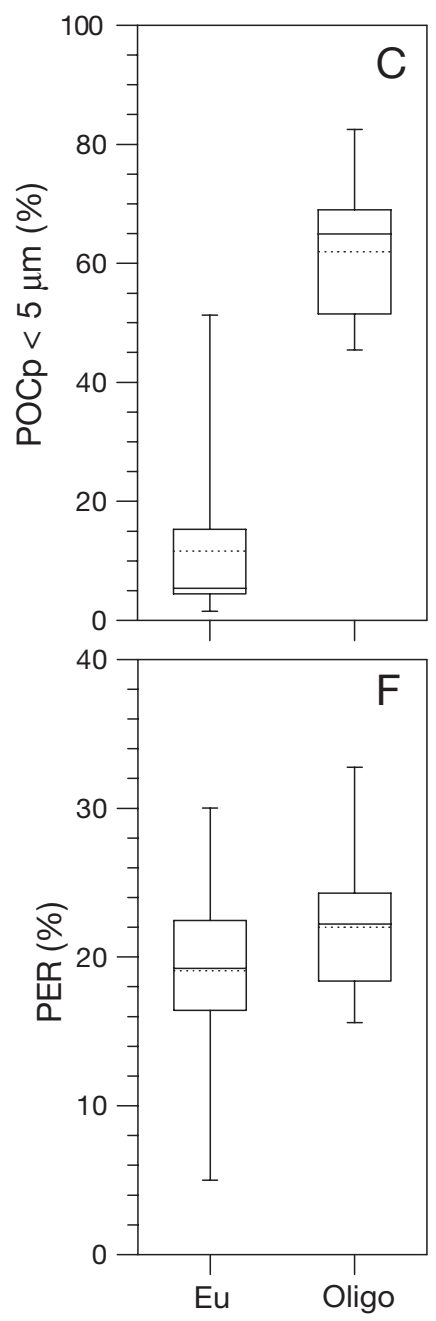

Fig. 8. Whisker plots showing the variability of (A) euphotic layer-integrated chl $a_{1}$ (B) the percentage of integrated $\mathrm{chl}$ $a$ in the $<5 \mu \mathrm{m}$ size fraction, (C) the percentage of integrated particulate organic carbon production (POCp) in the $<5 \mu \mathrm{m}$ size fraction, (D) integrated POCp, (E) integrated dissolved organic carbon production (DOCp) and (F) integrated percentage of extracellular release (PER) in eutrophic (Ría de Vigo, Eu) and oligotrophic (Celtic Sea during summer stratification, Oligo) conditions. Boxes indicate the 25th and 75th percentiles of the data, bars encompass all data, continuous horizontal lines represent the median and dashed horizontal lines represent the mean
Fig. 9. Relationship between euphotic layer-integrated particulate organic carbon production (POCp) and dissolved organic carbon production (DOCp), as measured in eutrophic

(Ría de Vigo, o) and oligotrophic waters (Celtic Sea, •)



(1991) were made by using glass fiber filters for sample filtration. It is now known that the use of these filters can lead to significant underestimates of DOCp (Karl et al. 1998), as a result of DOC adsorption onto the filters (Maske \& García-Mendoza 1994).

Our conclusions on the significance of DOCp are based on observations conducted in 2 contrasting ecosystems. It is clear that, in order to confirm the wider applicability of these conclusions, additional experiments should be carried out in other systems, particularly in the ultraoligotrophic waters of the subtropical gyres. However, the fact that our measurements of integrated POCp and DOCp were highly correlated across a wide productivity range makes it possible to estimate, to a first order, the importance of dissolved primary production from existing measurements of POCp. When applied, for instance, to the climatology of marine primary production obtained by Longhurst et al. (1995) from remote sensing data, our empirical model relating DOCp to POCp indicates that estimates of total production would increase from 45-50 to 


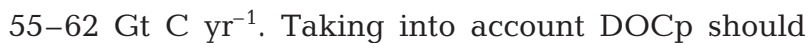
therefore contribute to a significant reduction in the discrepancy between global estimates of pelagic photosynthesis and respiration (del Giorgio \& Duarte 2002).

\section{CONCLUSIONS}

We have shown that the release of a substantial fraction of recent photosynthate in dissolved form occurs normally in widely different types of phytoplankton communities under contrasting environmental conditions, rather than taking place only under particularly adverse growth conditions or within particular algal assemblages. Moreover, the relative magnitude and underlying mechanisms of DOCp seem to be the same across a large productivity gradient. While this continuity makes it easier to estimate DOCp from measurements of POCp, the direct determination of dissolved primary production should be included in the standard set of measurements that are routinely applied in studies of aquatic productivity.

Acknowledgements. We thank principal investigator J. Sharples and P. M. Holligan for inviting P.C. and V.P. to participate on Cruise JR98 on board RRS 'James Clark Ross'. The ship's captain and crew are also acknowledged for their support during the work at sea. D. J. Hydes provided the nutrient concentration data and C. M. Moore helped with logistics both before and after the cruise. M. Espiñeira provided assistance with data processing. Cruise JR98 was part of the research project 'Physical-biological control of new production within the seasonal thermocline', funded by the UK National Environmental Research Council (NER/A/S/2001/ 00961). Our own research was made possible by grants from the Spanish Ministry of Science and Technology (REN20001248) and the Xunta de Galicia (PXIC30102PN) to E.M.

\section{LITERATURE CITED}

Baines SB, Pace ML (1991) The production of dissolved organic matter by phytoplankton and its importance to bacteria: patterns across marine and freshwater systems. Limnol Oceanogr 36:1078-1090

Banse K (1995) Zooplankton: pivotal role in the control of ocean production. ICES J Mar Sci 52:265-277

Barlow RG (1982) Phytoplankton ecology in the southern Benguela current. 3. Dynamics of a bloom. J Exp Mar Biol Ecol 63:239-248

Bjørnsen PK (1988) Phytoplankton exudation of organic matter: why do healthy cells do it? Limnol Oceanogr 33:151-154

del Giorgio PA, Duarte CM (2002) Respiration in the open ocean. Nature 420:379-384

Fogg GE (1983) The ecological significance of extracellular products of phytoplankton photosynthesis. Bot Mar 26:3-14

Grasshoff K, Kremling M, Ehrdardt M (1999) Methods of seawater analysis, 3rd edn. Wiley-VCH, Weinheim

Joint IR, Pomroy AJ (1983) Production of picoplankton and small nanoplankton in the Celtic Sea. Mar Biol 77:19-27
Joint IR, Owens NJP, Pomroy AJ (1986) Seasonal production of photosynthetic picoplankton and nanoplankton in the Celtic Sea. Mar Ecol Prog Ser 28:251-258

Jumars PA, Penry DL, Baross JA, Perry MJ, Frost BW (1989) Closing the microbial loop: dissolved carbon pathway to heterotrophic bacteria from incomplete ingestion, digestion and absorption in animals. Deep-Sea Res 36:483-495

Karl DM, Hebel DV, Bjorkman K, Letelier RM (1998) The role of dissolved organic matter release in the productivity of the oligotrophic North Pacific Ocean. Limnol Oceanogr 43:1270-1286

Lignell R (1992) Problems in filtration fractionation of ${ }^{14} \mathrm{C}$ primary productivity samples. Limnol Oceanogr 37:172-178

Longhurst A, Sathyendranath S, Platt T, Caverhill C (1995) An estimate of global primary production in the ocean from satellite radiometer data. J Plankton Res 17:1245-1271

Mague TH, Friberg E, Hughes DJ, Morris I (1980) Extracellular release of carbon by marine phytoplankton; a physiological approach. Limnol Oceanogr 25:262-279

Malinsky-Rushansky N, Legrand C (1996) Excretion of dissolved organic carbon by phytoplankton of different sizes and subsequent bacterial uptake. Mar Ecol Prog Ser 132: 249-255

Marañón E, Cermeño P, Fernández E, Rodríguez J, Zabala L (2004) Significance and mechanisms of photosynthetic production of dissolved organic matter in a coastal eutrophic ecosystem. Limnol Oceanogr 49:1652-1666

Maske H, García-Mendoza E (1994) Adsorption of dissolved organic matter to the inorganic filter substrate and its implications for ${ }^{14} \mathrm{C}$ uptake measurements. Appl Environ Microbiol 60:3887-3889

Meon B, Kirchman DL (2001) Dynamics and molecular composition of dissolved organic material during experimental phytoplankton blooms. Mar Chem 75:185-199

Morán XAG, Estrada M (2001) Short-term variability of photosynthetic parameters and particulate and dissolved primary production in the Alboran Sea (NW Mediterranean). Mar Ecol Prog Ser 212:53-67

Nagata T (2000) Production mechanisms of dissolved organic matter. In: Kirchman DL (ed) Microbial ecology of the oceans. Wiley-Liss, New York, p 121-152

Norrman B, Zweifel UL, Hopkinson CS, Fry B (1995) Production and utilization of dissolved organic carbon during an experimental diatom bloom. Limnol Oceanogr 40:898-907

Obernosterer I, Herndl GJ (1995) Phytoplankton extracellular release and bacterial growth: dependence of the inorganic N:P ratio. Mar Ecol Prog Ser 116:247-257

Raven JA (1986) Physiological consequences of extremely small size for autotrophic organisms in the sea. In: Platt T, Li WKW (eds) Photosynthetic picoplankton. Can Bull Fish Aquat Sci 214:1-70

Sharp JH (1977) Excretion of organic matter by marine phytoplankton: do healthy cells do it? Limnol Oceanogr 22: 381-399

Strom SL, Benner R, Ziegler S, Dagg MJ (1997) Planktonic grazers are a potentially important source of marine dissolved organic carbon. Limnol Oceanogr 42:1364-1374

Teira E, Pazó MJ, Serret P, Fernández E (2001) Dissolved organic carbon production by microbial populations in the Atlantic Ocean. Limnol Oceanogr 46:1370-1377

Wood AM, Van Valen LM (1990) Paradox lost? On the release of energy-rich compounds by phytoplankton. Mar Microb Food Webs 4:103-116

Zlotnik I, Dubinsky Z (1989) The effect of light and temperature on DOC excretion by phytoplankton. Limnol Oceanogr 34: 831-839

Submitted: December 20, 2004; Accepted: May 21, 2005

Proofs received from author(s): July 29, 2005 